DOI: $10.34185 / 1991-7848.2018 .01 .02$

UDC 169.162

Y. Karakash, T.Baranova

\title{
BASIC AREAS OF THE SECONDARY ENERGY RESOURCES USE IN THE BLAST-FURNACE IRONMAKING AND APPLICATION OF HEAT PUMPS
}

\begin{abstract}
Under the present-day conditions of blast-furnace shop operation, the use of low-potential SERs seems to be the most promising measure with regard to reduction of cast-iron production cost. Proposed measures on improvement of blast-furnace gas calorific power due to the reduction of its moisture content allow the blast-furnace air temperature increase and coke consumption reduction. Also proposed is partial transfer of excess heat from the blast-furnace gas to combustion air by means of the system of heat pumps, which allows increase in calorimetric combustion temperature.

In this paper, main parameters are calculated of the heat pump system operation under the conditions of blast-furnace shop at the increased top gas temperature. This paper presents heat pump system operating efficiency and determines conversion factor for the specific conditions (COP).
\end{abstract}

Keywords: blast furnace, heat pump, secondary resources, energy.

\section{Introduction}

Energy consumption pattern broken down by main process areas of the metallurgical industry in 2010-2016 is as follows: sintering process - 6-8\% of total industry-consumed energy; coking process $-4,5-6 \%$; blast-furnace ironmaking $-47-50 \%$; steelmaking $-6-11 \%$ (at this processing stage, number of electric furnaces increases sharply); rolling process - 6-9\%; refractory production - 1-2\%; electric power installations - $12-14 \%$; other consumers - up to $7 \%$.

Coefficient of major SERs utilization does not exceed $40 \%$, which indicates low efficiency of recuperation plants and systems. Since blast-furnace processing is one of primary energy consumers in the industry, improvement of its operating efficiency and introduction of new energy-saving technologies would allow considerable reduction in total industry-wide power costs.

Pulverized coal injection technology is used in growing number of blast furnaces.

Depending on the used technology and PCF quality, this measure provides coke consumption savings of $40 \%$ to $10 \%$. Previously, coke consumption for cast-iron production made $500-550 \mathrm{~kg}$ per ton of cast-iron, and now some plants reduced this value to $270-237 \mathrm{~kg}$ of coke per ton of cast-iron due to the use of PCF.

However, number of processing complexities is related to the PCF preparation process. Primarily, this is proper drying prior to injection into furnace through air tuyeres. Natural and blastfurnace gases can be used for drying, as well as combustion products escaping from hot-blast stove being the secondary energy resource (SER), of which efficient use would result in the cast-iron production cost reduction. It might be well to evaluate the SER use at the blast furnaces in presentday conditions.

\section{Performance potential of blast-furnace complex constituents with regard to the SER usage}

Major portion of total thermal energy generated in furnace shaft and carried in with the hot air blast is lost:

1) Blast furnace;

2) Blast furnace gas treatment system;

3) Hot stoves.

1) Blast furnace - for the physical and chemical processes inside furnace shaft, for the change of enthalpy and melting of charge components, for the finished cast-iron and slag overheat, and for

(C) Karakash Y., Baranova T., 2018 
heating the heat-transfer medium and change of its aggregate state in the cooling system; in addition, part of thermal energy is carried off with the furnace top gas.

The most practicable SER sources are sensible heat of cooling system heat-transfer medium, sensible heat of top gas and partial usage of the overheated liquid slag heat. However, such SER usage is scarcely adopted, except for the occasional use of heat-recovery boilers in the evaporation cooling systems [2]. The use of sensible heat of overheated liquid cast-iron is challenging target even in theoretical terms, because its overheating is relatively low.

In the blast furnace cooling systems, water is the basic heat-transfer medium; in the evaporation cooling systems, it may exist both in gaseous and liquid states. At the most enterprises, water is cooled with the use of cooling towers or special cooling ponds without sensible heat utilization.

2) Blast furnace gas treatment system.

Sensible heat of furnace top gas is main and sole heat resource at this facility. When leaving the blast furnace, top gas temperature ranges from $170^{\circ} \mathrm{C}$ to $450^{\circ} \mathrm{C}$ depending on blast-furnace smelting features. While cleaned blast-furnace gas temperature makes from $15^{\circ} \mathrm{C}$ to $65^{\circ} \mathrm{C}$, respectively. The use of high temperature of top gas in conventional heat exchangers upstream the gas treatment system is complicated due to considerable dust content (up to $20 \mathrm{~g} / \mathrm{m} 3$ ). Conventional heat exchangers are virtually inoperative at such dust content in one of heat-transfer media.

3) Hot-blast stoves.

Main secondary thermal energy source is chimney gas with temperature $180-250^{\circ} \mathrm{C}$ from hotblast stoves [3]. These SERs are successfully used at many enterprises; however, there is number of limitations as well, which reduce sensible heat utilization efficiency. These include minimum temperature condition for fumes from heat exchanger; temperature must be higher than or equal to $110-230^{\circ} \mathrm{C}$, since it is the level of dew point of sulphuric acids contained in fumes. When fume temperature drops below the indicated value, condensed moisture is deposited on the heat exchanger walls resulting in the acid corrosion. Such p2/henomena cases were observed at the Zaporizhstal Iron \& Steel Works in 2005.

Thus, it may be concluded that SER are only partly used in the most example cases [4].

\section{The use of the system of heat pumps and their calculation for the blast-furnace shop conditions}

The study proposes the use of the sensible heat utilization system based on heat pumps and heat transfer tubes. This system includes intermediate heat-transfer medium and is capable of operation with low-grade sources of sensible heat [5].

One of proposed solutions for the set problem is extraction of energy from the blast-furnace gas, both upstream and downstream the gas treatment system. Here, heat exchanger with intermediate heat-transfer medium (Freon or oil) has not necessarily contact directly with the dustcarrying top gas, but can be securely attached to the external surface of top gas discharge duct. In this case, heat amount taken from the top gas would depend on the heat-exchange surface area, aggregate coefficients of heat transmission from surface to the gaseous medium at the "hot" and "cold" sides, and on the heat-transfer resistance in the points of tubing contact with the top gas line surface. On the average, furnace top gas temperature could be decreased by $70-120^{\circ} \mathrm{C}$ prior to the entry into gas treatment system. Alternatively, heat exchanger with intermediate heat-transfer medium could be installed inside the air duct supplying combustion air into hot-blast stoves (HS). Such installation efficiency could make $45-80 \%$, which allows hot blast temperature increase by $10-15^{\circ} \mathrm{C}$. At the total reduction in blast-furnace gas consumption for HS heating by $6-8 \%$, average value of savings on specific energy consumption in the blast-furnace processing would make approximately $0.5 \%$ [6]. When engineering the proposed system, installation of compressor equipment and expansion valves (included in every heat pump system) could be eliminated, as well as the change of aggregate state of 
intermediate heat-transfer medium. Completed system is the system of heat exchangers with intermediate high-temperature heat-transfer medium. However, if temperature at the "hot" side of such system is below $180-200^{\circ} \mathrm{C}$, such equipment modification seems being of little promise. Moreover, the use of classic heat pump or heat transfer tubes is only practical for the blast-furnace gas temperature downstream the gas treatment system. Gas temperature downstream the gas treatment system makes $40-65^{\circ} \mathrm{C}$. It should be noted that heat utilization at lower temperatures is quite impractical. In our opinion, primary objective in this case is not so much utilization of small amount of sensible heat as total blast-furnace gas temperature reduction downstream the burners. The matter is that the blast-furnace gas with relatively high temperature $\left(45^{\circ} \mathrm{C}\right.$ and over) has sufficiently high moisture content, which reduces its calorific heat value. The work [7] considers in some detail the blast-furnace gas moisture content data from existing furnaces versus temperature and impact of these parameters on the eventual combustion temperature in HS. The use of heat pump with Freon-type heat-transfer medium in the internal circuit is proposed for this heat utilization and blast-furnace gas temperature reduction.

Following is calculation of such heat pump system for operation with low-grade thermal energy source under the blast-furnace shop conditions.

Mass flow of refrigerating fluid:

$$
G_{f}=\frac{Q_{e v}}{i_{\text {out }}-i_{\text {in }}}=\frac{1376}{701-488}=6,5, \mathrm{~kg} / \mathrm{s} .
$$

Volume flow of refrigerating fluid:

$$
V_{f}=\frac{G_{f}}{\rho_{f}}=\frac{6,5}{15,4}=0,42,
$$

where the density of freon R22 at boiling point is approximately $-10{ }^{\circ} \mathrm{C}$

After inserting the necessary numerical values for determination of compressor power:

$$
N=\frac{15,4 \cdot 0,42 \cdot 16}{0,65 \cdot 0,68 \cdot 0,71}=330, \mathrm{~kW} .
$$

\section{Determination of heat pump COP}

COP is transformation coefficient showing the ratio of generated and thermal energy to electric power consumed by the heat pump. Coefficient can also be defined as the condenser heating effect to screw compressor power ratio.

Heat pump COP is determined according to following formula:

$$
\eta_{\text {COP }}=\frac{Q_{\text {con }}}{N}=\frac{1378}{330}=4,2 .
$$

Based on calculation of this heat pump COP, we come to conclusion that heat pump generates thermal energy 4.2 times as much as its electric power consumption for work execution.

\section{Conclusion}

Primary advantage of the proposed heat pump system is integration in the existing top gas treatment system. The proposed system does not require major reconstruction of existing equipment and features relatively small dimensions.

In addition to the primary objective of increasing the blast-furnace gas calorific power (due to the moisture content reduction), a few other serious practical problems are solved. One of such problems is increasing the temperature of combustion air supplied to hot-blast stoves. Sensible heat carried by air into the combustion zone allows calorimetric temperature increase by $3-5^{\circ} \mathrm{C}$ in the combustion zone, which would result in the blast-furnace air temperature increase and coke consumption reduction.

Furthermore, implementation of this system would enable production of substantial amount of the chemically purified water. The blast-furnace gas cooling in the heat pump evaporator would yield 
up to $200 \mathrm{~g}$ of $\mathrm{H} 2 \mathrm{O}$ per $1 \mathrm{~m} 3$ of blast-furnace gas. This water could be further used in the blast-furnace shop cooling system.

\section{REFERENCES}

1. I.N. Karp, A.N. Zaivy Energy saving technologies in metallurgy // Eenvironmental technologies and resource saving, 2006 . - p. 13-20 (in Russian).

2. Y.I. Rozengart Secondary energy resources of ferrous metallurgy Kyiv.: High school, 1988.- 328 p. (in Russian)

3. Karakash Y., Gres L.. Recirculation of waste gases in heat installations of agglomerate production/Acta Metallurgica Slovaca. - 2000. - № 3. - P. 135-138.

4. Karakash Y., Gres L., Fleyschman Y. New approaches to the creation of high-efficiency blast air heaters/ Metalurgicheskaya teplotechnika - 2009. 1(16) - p. 65-71 (in Russian)

5. D. Reay, D. Macmichael Heat pumps. Design and applications Pergamon press, Oxford, 1979

6. Karakash Y., Gres L., Fleyschman Improving the energy efficiency of blast-furnace blast heating in blast furnaces in operation by installing a system of heat exchangers for heating the components of combustion and upgrading the air heaters / Metal and casting of Ukraine, № 5, 2014 Dnipro (in Russian)

7. Gres L., Karpenko S., Milenina Heat-exchangers for blast furnaces - Dnipropetrovsk^ Porogi, 2012 - 491 p. - ISBN 978-617-518-207-9 (in Russian).

Received 17.01.18

\section{ИСПОЛЬЗОВАНИЕ НИЗКОПОТЕНЦИАЛЬНЫХ ВТОРИЧНЫХ ЭНЕРГЕТИЧЕСКИХ РЕСУРСОВ И ПРИМЕНЕНИЕ ТЕПЛОВЫХ НАСОСОВ В ДОМЕННОМ ПРОИЗВОДСТВЕ}

В современных условиях работы доменного цеха использования низкопотенциальных ВЭР представляется наиболее перспективным мероприятием, с точки зрения снижения себестоимости производства чугуна. Предлагаемые меры по повышению калорийности доменного газа за счет снижения в его содержания влаги позволяют повысить температуру доменного дутья и уменьшить расход кокса. Также предлагается с помощью системы тепловых насосов передавать часть избыточной теплоты от доменного газа в воздух горения, что позволяет повышать калориметрическую температуру горения топлива.

В работе рассчитаны основные параметры работы системы тепловых насосов в условиях доменного цеха при повышенной температуре колошникового газа. Рассмотрена эффективность работы системы.

Ключевые слова: доменное производство, тепловой насос, вторичные ресурсы, энергетика.

\section{ВИКОРИСТАННЯ НИЗЬКОПОТЕНЦІЙНИХ ВТОРИННИХ ЕНЕРГЕТИЧНИХ РЕСУРСІВ І ЗАСТОСУВАННЯ ТЕПЛОВИХ НАСОСІВ У ДОМЕННОМУ ВИРОБНИЦТВІ}

В сучасних умовах роботи доменного цеху використання низькопотенційних ВЕР представляється найбільш перспективним заходом 3 точки зору зниження собівартості виробництва чавуну. Пропоновані заходи щодо підвищення калорійності доменного газу за рахунок зниження у його вмісту вологи дозволяють підвищити температуру доменного дуття i зменшити витрату коксу. Також пропонується за допомогою системи теплових насосів передавати частину надлишкової теплоти від доменного газу до повітря горіння, що дозволяє підвищувати калориметричну температуру горіння палива.

В роботі розраховані основні параметри роботи системи теплових насосів в умовах доменного цеху при підвищеній температурі колошникового газу. Розглянуто ефективність роботи системи теплових насосів і визначено коефіцієнт перетворення для заданих умов (COP).

Ключові слова: доменне виробництво, тепловий насос, вторинні ресурси, енергетика. 
Karakash Y. - PhD, ass.prof., Ecology, Ecology, Heat-Transfer and labour protection department, National Metallurgical academy of Ukraine.

Каракаш Ю. - кандидат технічних наук, кафедра теплообміну, охорони праці та екології, Національна металургійна академія України.

Baranova T. - assistant, Ecology, Ecology, Heat-Transfer and labour protection department, National Metallurgical academy of Ukraine.

Баранова T. - асистент кафедри кафедра теплообміну, охорони праці та екології, Національна металургійна академія України. 